\title{
Human gnathostomiasis: a neglected food-borne zoonosis
}

\author{
Guo-Hua Liu' ${ }^{1,2}$, Miao-Miao Sun², Hany M. Elsheikha ${ }^{3}$, Yi-Tian Fu' ${ }^{1}$, Hiromu Sugiyama ${ }^{4}$, Katsuhiko Ando ${ }^{5}$, \\ Woon-Mok Sohn ${ }^{6}$, Xing-Quan Zhu ${ }^{7^{*}}$ and Chaoqun Yao ${ }^{8^{*}}$
}

\begin{abstract}
Background: Human gnathostomiasis is a food-borne zoonosis. Its etiological agents are the third-stage larvae of Gnathostoma spp. Human gnathostomiasis is often reported in developing countries, but it is also an emerging disease in developed countries in non-endemic areas. The recent surge in cases of human gnathostomiasis is mainly due to the increasing consumption of raw freshwater fish, amphibians, and reptiles.

Methods: This article reviews the literature on Gnathostoma spp. and the disease that these parasites cause in humans. We review the literature on the life cycle and pathogenesis of these parasites, the clinical features, epidemiology, diagnosis, treatment, control, and new molecular findings on human gnathostomiasis, and social-ecological factors related to the transmission of this disease.

Conclusions: The information presented provides an impetus for studying the parasite biology and host immunity. It is urgently needed to develop a quick and sensitive diagnosis and to develop an effective regimen for the management and control of human gnathostomiasis.
\end{abstract}

Keywords: Gnathostoma spp., Gnathostomiasis, Food-borne zoonosis

\section{Background}

Human gnathostomiasis, a food-borne zoonosis, is caused by the third-stage larvae $\left(\mathrm{L}_{3}\right)$ of Gnathostoma spp. [1]. Humans are infected by these nematodes by consuming raw or undercooked fish, frogs, snakes or poultry that contain the $\mathrm{L}_{3}$ [2]. The most common clinical signs and symptoms of the disease are migratory cutaneous swellings and eosinophilia. In severe cases, $\mathrm{L}_{3}$ also invade internal organs and tissues such as the liver, eyes, nerves, spinal cord and brain, which can result in blindness, nerve pain, paralysis, coma and even death [3].

\footnotetext{
*Correspondence: xingquanzhu1@hotmail.com; chyao@rossvet.edu.kn

${ }^{7}$ College of Veterinary Medicine, Shanxi Agricultural University, Taigu,

Shanxi 030801, People's Republic of China

${ }^{8}$ Department of Biomedical Sciences and One Health Center

for Zoonoses and Tropical Veterinary Medicine, Ross University School

of Veterinary Medicine, P.O. Box 334, Basseterre, St Kitts and Nevis

Full list of author information is available at the end of the article
}

The first human case of gnathostomiasis was reported from Thailand in 1889, and was attributed to infection by Cheiracanthus siamensis (Levinseen 1889). Shortly afterwards, Leiper (1891) found that C. siamensis was morphologically identical to Gnathostoma spinigerum, and thus considered the former a synonym of the latter. However, the life cycle of G. spinigerum was not elucidated until 1936 [4]. To date, approximately 5000 cases of human gnathostomiasis have been reported worldwide, mainly from endemic areas in Japan and China, Thailand and other parts of Southeast Asia, Mexico, and Colombia and Peru in South America [1,3]. Gnathostomiasis has also been reported, albeit infrequently, in travelers from developed countries who have visited endemic areas [3, 5-8]. Furthermore, autochthonous gnathostomiasis has been reported in several non-endemic countries [9-12]. Therefore, human gnathostomiasis is considered an emerging global zoonosis $[3,13]$.

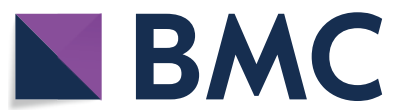

(c) The Author(s) 2020. This article is licensed under a Creative Commons Attribution 4.0 International License, which permits use, sharing, adaptation, distribution and reproduction in any medium or format, as long as you give appropriate credit to the original author(s) and the source, provide a link to the Creative Commons licence, and indicate if changes were made. The images or other third party material in this article are included in the article's Creative Commons licence, unless indicated otherwise in a credit line to the material. If material is not included in the article's Creative Commons licence and your intended use is not permitted by statutory regulation or exceeds the permitted use, you will need to obtain permission directly from the copyright holder. To view a copy of this licence, visit http://creativeco mmons.org/licenses/by/4.0/. The Creative Commons Public Domain Dedication waiver (http://creativecommons.org/publicdomain/ zero/1.0/) applies to the data made available in this article, unless otherwise stated in a credit line to the data. 
The increase in reports of human gnathostomiasis may be due to changes in eating habits as a result of improved living standards, and also in improvements in health care systems for disease reporting [14]. The eradication of gnathostomiasis is challenging because of the worldwide distribution of Gnathostoma spp. and increasing demand for exotic dishes such as marinated or raw fish $[1,14,15]$. Therefore, an effective prevention and control strategy should ideally be implemented for this disease. Here, we comprehensively review several aspects of human gnathostomiasis and discuss future prospects for the improvement of public perception of the importance of this parasitic disease.

\section{Gnathostoma spp. and their life cycles}

A gnathostome nematode was first discovered in 1836 in the stomach of a young tiger that had died of aortic rupture at London Zoo [16]. Since then, Gnathostoma spp. (Nematoda: Gnathostomatidae) have been determined to be the etiological agents of human gnathostomiasis [17]. Among the 12 species in the genus, at least five, G. binucleatum, G. doloresi, G. hispidum, G. nipponicum and G. spinigerum, cause human disease [18, 19]. The species most frequently found in humans and most widely distributed around the world is G. spinigerum; G. binucleatum is found in the Americas [1]. Sporadic cases caused by G. doloresi, G. hispidum, and G. nipponicum have been documented in Asia [20-23].

Gnathostome eggs are oval in shape and have a mucoid plug at one or both ends, depending on the species [24]. The early $\mathrm{L}_{3}\left(\mathrm{EL}_{3}\right)$ and the advanced $\mathrm{L}_{3}\left(\mathrm{AdL}_{3}\right)$ of G. spinigerum in the second intermediate host usually measure $0.85-1.38$ in length $\times 0.10-0.15 \mathrm{~mm}$ in diameter and $2.30-4.40$ in length $\times 0.25-0.43 \mathrm{~mm}$ in diameter, respectively. $\mathrm{AdL}_{3}$ have a characteristic head bulb of $93 \times 221 \mu \mathrm{m}$ on average, which often bears four rows, and occasionally five rows, of hooklets, a long muscular esophagus $0.63-1.22 \mathrm{~mm}$ in length and two pairs of cervical sacs $0.33-0.75 \mathrm{~mm}$ in length.

Gnathostoma nematodes require two intermediate hosts and one definitive host to complete their life cycles (Fig. 1). In general, the adult worms live and spawn in a tumor-like mass in the stomach of the definitive host (e.g., cat, tiger, leopard or dog in the case of G. spinigerum). The eggs are released in the host's feces into the environment, where they develop and hatch into the first-stage larvae $\left(\mathrm{L}_{1}\right)$ in freshwater within 7 days at $28{ }^{\circ} \mathrm{C} . \mathrm{L}_{1}$ are then ingested by the first intermediate host, freshwater copepods (usually of the genera Cyclops, Eucyclops and Mesocyclops), where they develop into the second-stage larvae $\left(\mathrm{L}_{2}\right)$. When the infected copepods are consumed by the second intermediate host such as a fish or tadpole, $\mathrm{L}_{2}$ migrate into the new host's muscular tissue where they develop into $\mathrm{L}_{3}$. If $\mathrm{L}_{3}$ in the second intermediate host, transport or paratenic host are ingested by a definitive host (e.g., dogs, cats, pigs or weasel), they migrate to the liver and the abdominal cavity after penetrating the gastric wall. Four weeks later they return to the gastric wall [1] and develop into adults. This development from L3 to adult usually takes 6-8 months. The definitive host starts to excrete the parasite eggs into the environment in its feces approximately 8 to 12 months after ingestion of $\mathrm{L}_{3}[25,26]$. When $\mathrm{L}_{3}$ are eaten by paratenic hosts such as frogs, snakes, birds and mammals including humans, they migrate through their tissues and remain encysted in their muscles.

Human gnathostomiasis can occur through three modes of transmission: oral, transplacental and skin wounds. However, this parasitic disease is mainly caused by the ingestion of raw or undercooked meat of intermediate hosts, such as fish, frogs, snakes or poultry, which contains $\mathrm{L}_{3}$ [27]. Oral infection can also occur through drinking water contaminated with infected copepods [28]. Transplacental infection only occurs in pregnant women with a heavy infection of gnathostome larvae, which is rare [29]. $\mathrm{L}_{3}$ harbored in the infected meat of intermediate hosts can penetrate the skin of humans, particularly through wounds [30].

\section{Pathogenesis and clinical presentation}

Humans are not definitive hosts of Gnathostoma spp., and $\mathrm{L}_{3}$ cannot mature into adults in them [31]. $\mathrm{L}_{3}$ can, however, cause damage to their tissues and/or organs by inducing host reactions, like inflammation and allergy, when they migrate and secrete excreta and toxins [32]. $\mathrm{L}_{3}$ may cause damage to vital organs and the central nervous system (CNS), resulting in detrimental outcomes including the sudden death of an infected individual [33, 34]. The larvae release excretory-secretory products (ES) with divergent functions that contribute to different parasite behaviors including cutaneous and visceral larva migrans $[35,36]$. Recent studies have demonstrated that G. spinigerum ES antigens modulate monocyte function via inhibition of Fc gamma receptor I expression, and trigger apoptosis of the peripheral blood mononuclear cells mainly via the extrinsic pathway $[37,38]$.

Gnathostoma larvae can migrate to the skin though subcutaneous tissue, and penetrate other tissues and organs including the eyes, ears, breasts, lungs, gastrointestinal tract, thoracic spinal cord, genitourinary system and CNS $[8,39]$. Clinical features mostly manifest as cutaneous and visceral migrans, depending on which parts of the body have been invaded. Within 1 or 2 days of ingestion, a Gnathostoma larva migrates through the gastrointestinal tract wall and the liver. Patients may develop systemic symptoms and signs such as fever, 
anorexia, nausea, vomiting, abdominal pain, joint pain etc., which may last for more than 2 weeks. Cutaneous gnathostomiasis involves migrating lumps, which are the most important features in diagnosis of the disease. Clinical manifestations of the various organs infected by Gnathostoma spp. differ. A significant increase in eosinophils is common and can be used as a basis for auxiliary diagnosis [40]. The most common form of infection is larval migration within skin tissues, which causes a great amount of pain and lasts for 3-4 weeks. The pathogenesis of gnathostomiasis remains largely unknown. Nevertheless, it is plausible that the symptoms and signs of the disease are due to the mechanical damage caused by larval migration, the inflammation and infection that is secondary to the mechanical damage, the combined effects of reactions to larval ES and the activation of an immune response in the host.

\section{Cutaneous gnathostomiasis}

Cutaneous gnathostomiasis, which is always accompanied by nodular migratory panniculitis [40], is the most common clinical manifestation of human gnathostomiasis. The larvae spread throughout the body (limbs, face, back, abdomen, armpits, breasts etc.) by migrating through the epidermis, dermis and subcutaneous tissue, causing cutaneous larva migrans and resulting in skin irritation, pain and pruritus [41]. Reports of six cases of cutaneous gnathostomiasis noted that it takes an average of 12 days for the condition to be diagnosed and for a patient to start treatment $[42,43]$. In these cases, larvae were found in the dermis and subcutaneous tissue by pathological examination of the skin lesions, which were infiltrated with numerous eosinophils along with low numbers of lymphocytes and neutrophils. $\mathrm{L}_{3}$ can survive in the human body for a very long period of time; episodes of swelling may become brief and less intense, and symptoms may recur intermittently for more than 10

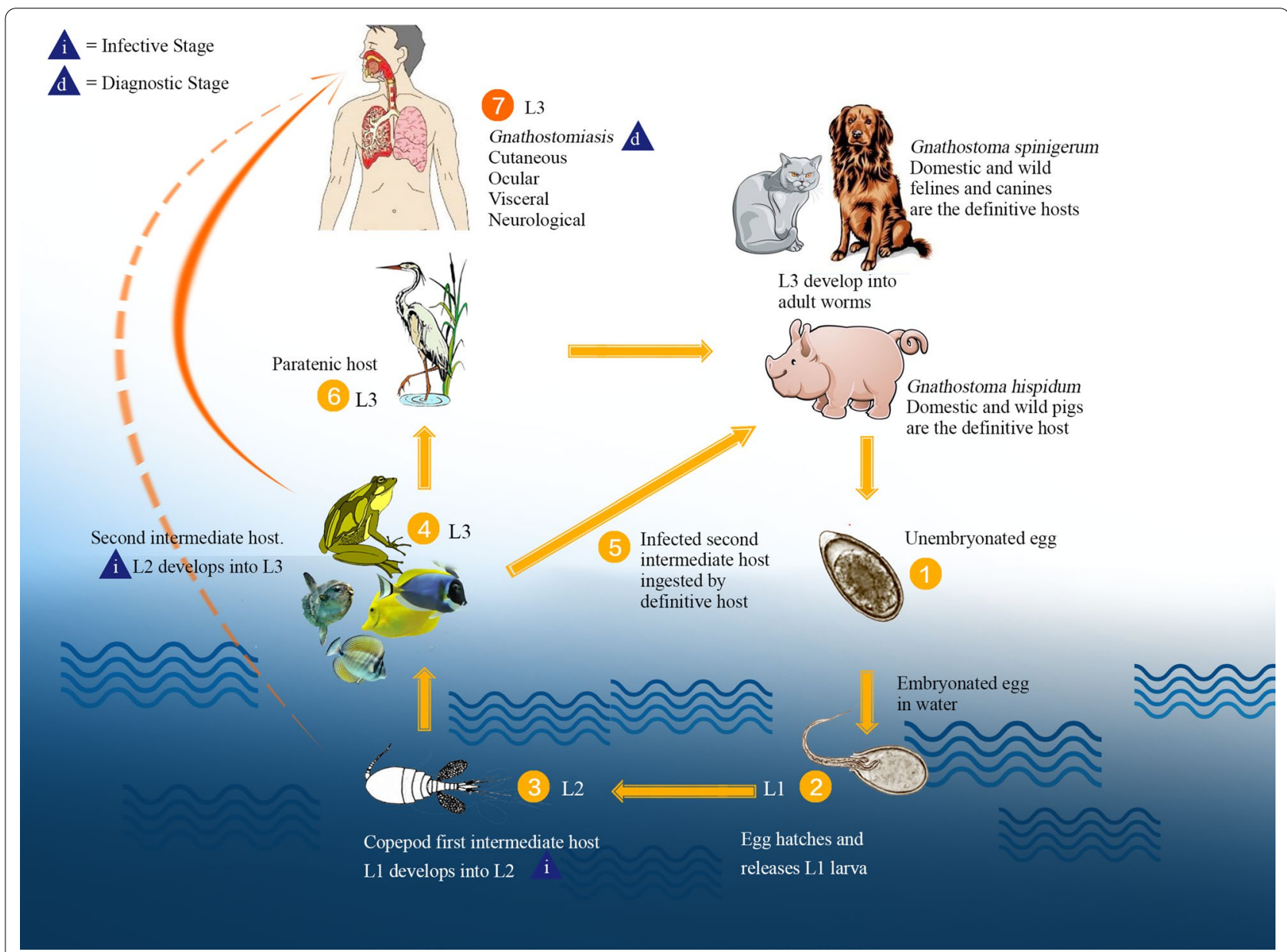

Fig. 1 Life cycle of Gnathostoma. L1 First-stage larva, L2 second-stage larva, L3 third-stage larva. Adapted from the Centers for Disease Control and Prevention (CDC) DPDx website (https://www.cdc.gov/dpdx/gnathostomiasis/index.html) 
years in untreated patients. Cutaneous gnathostomiasis should be suspected in a patient with creeping eruption, migratory swellings, a skin abscess or nodules [44].

\section{Visceral gnathostomiasis}

Gnathostoma larvae, which are highly invasive, can migrate throughout various internal organs, resulting in a wide range of symptoms and signs that can affect almost any part of the body. In the visceral disease, larvae may cause intermittent symptoms for a long period of time or, without proper treatment, until the host's death [1].

\section{Ocular manifestations}

Gnathostoma larvae can invade the eyes, leading to external and internal ocular lesions with inflammation, and other symptoms and signs such as subarachnoid hemorrhage, and even permanent vision loss [34, 45]. Clinical manifestations such as occasional eyelid edema, conjunctival pain and conjunctival erythema have also been reported [46]. Larvae in the eyes can be visualized, and are generally found in the anterior chamber. With surgical removal of larvae, visual performance can be recovered completely, but optic neuropathy can occur leading to permanent blindness $[47,48]$.

\section{Auricular manifestations}

$\mathrm{L}_{3}$ can damage the inner ear leading to tinnitus, dizziness, hearing loss and other symptoms.

\section{Pulmonary manifestations}

Clinical manifestations in patients with pulmonary involvement include fever, cough, chest pain, nodular densities and pneumothorax, mostly accompanied by complicated pleural effusion [49]. Peripheral blood eosinophils in patients with pulmonary manifestations were found to be significantly increased [29]. Lung cancer patients infected with Gnathostoma spp. suffered repeated fevers, cough, chest tightness and other respiratory non-specific symptoms [1].

\section{Gastrointestinal manifestations}

Gastrointestinal manifestations of gnathostomiasis in humans include sharp abdominal pain, anorexia, vomiting, and indigestion as the larvae invade the stomach wall, which causes a large area of gastric mucosal inflammatory congestion and can result in a gastric ulcer or gastric perforation, and even acute right iliac fossa pain [1].

\section{Genitourinary manifestations}

Larvae can pass through bladder tissue into the urine, and symptoms of this may include hematuria, the sensation of a foreign body in the urine, etc. Urinary tract disease is rare [50-52].

\section{CNS manifestations}

Invasion of the CNS by Gnathostoma $\mathrm{L}_{3}$ causes neurognathostomiasis [53], the severest form of visceral disease. Patients mainly present with symptoms of radiculomyelitis or radiculomyeloencephalitis, eosinophilic meningitis or meningoencephalitis, subarachnoid and even intracerebral hemorrhage [54-56]. Human neurognathostomiasis has a long history, with the first case reported in 1949 and the first pathologic evidence documented in 1967 [57, 58]. Since then, the detection of neurognathostomiasis has increased steadily due to improved diagnostic techniques.

Gnathostoma $\mathrm{L}_{3}$ are highly invasive, and migrate by releasing various molecules, such as cysteine proteases and matrix metalloproteinases (MMPs) into the invaded micro-environment to promote their penetration and invasion of organs [59, 60]. Larvae invade the CNS directly through the loose connective tissues of the neural foramina of the skull base, and the intervertebral foramina of the spine and vessels [61]. Radiculomyelitis can be caused by larvae entering the nerve roots of the spinal cord [62]. Migration of the larvae within the CNS can also cause mechanical injury, parenchymal damage and subarachnoid hemorrhage [63]. The salient symptoms and signs of neurognathostomiasis are the sudden onset of severe radicular pain with headache followed by loss of function of the cranial nerves and paralysis of the extremities, or quadriparesis with bladder dysfunction; the initial pain is characteristically followed by degrees of paralysis, ranging from weakness to thorough paralysis of one to all four limbs [56, 64]. Further migration of the larvae within the CNS may lead to a multiplicity of rapidly progressing lesions beyond the extent of cerebral edema [1].

Direct mechanical damage to the CNS can also occur, as the relatively large $L_{3}$, averaging $3-4 \mathrm{~mm}$ in length, can migrate through neural or vascular tissue [65]. Larvae burrowing through a cerebral arteriole may cause subarachnoid hemorrhage. The universal presence of eosinophilic pleocytosis indicates that inflammatory responses to larval invasion could lead to further tissue destruction [64].

Should migrating larvae invade vital structures in the brain stem, death can occur after several days following the onset of symptoms [56]. High-resolution magnetic 
resonance imaging (MRI) can be used to image the tracks of Gnathostoma $\mathrm{L}_{3}$, and greatly increases the accuracy of diagnosis of neurognathostomiasis [66].

\section{Epidemiology}

Gnathostoma spp. have a worldwide geographical distribution. About 5000 cases of human gnathostomiasis have been reported worldwide since the first one was described in Thailand in 1889. Gnathostomiasis is endemic in Japan and Thailand [1], and has been sporadically reported in numerous countries around the world (Fig. 2).

Five Gnathostoma species have been found to infect humans. G. spinigerum is commonly found in China, India, Japan and Southeast Asia; G. hispidum is found in Asia, Australia and Europe; G. doloresi is found in Southeast Asia; G. nipponicum is distributed in Korea and Japan [1]; and G. binucleatum is found in Mexico and some South American countries.

In Japan, 3182 cases of human gnathostomiasis were reported from 1911 to 1995 , with 103 cases in which a Gnathostoma worm was detected [22, 54, 67-74]. Seventy three cases were reported from 1996 to 2012, with the detection of $\mathrm{L}_{3}$ in 29 cases (personal communication, unpublished data). In Thailand, there have been 1079 recorded cases of human gnathostomiasis. The seroprevalence of Gnathostoma in humans was 62.5\% (531/849) in Bangkok, Thailand between 2000 and 2005 [75]. The high prevalence of gnathostomiasis in this population might be partly due to the local custom of eating raw fish [75]. In China, the first case of human gnathostomiasis was reported in Xiamen, Fujian province in 1919. Eightysix cases ( 83 of which were caused by G. spinigerum, two by $G$. hispidum and one by G. doloresi) were reported between 1918 and 2014, mostly in southern and eastern China [41, 67, 68, 76-80]. Among these cases of human gnathostomiasis, more than $90 \%$ were due to the ingestion of raw or undercooked food (mostly fish, including eels and loach, but also frogs and snakes) [81].

\section{Social-ecological status}

Although the presence of intermediate hosts is necessary for the endemism of gnathostomiasis, dietary habits are a key factor in its transmission. As mentioned earlier, eels, loaches, frogs and snakes, considered delicacies by some ethnic populations, are the most important second intermediate hosts of Gnathostoma spp. [1]. An increasing number of people can afford these delicacies due to the improvement of living standards. Freshwater fish (including eels and loaches), either raw or marinated in lemon juice, such as in sushi, sashimi and ceviche, are very popular food items worldwide [82, 83]. In many countries and regions, offering raw fish to guests is deemed a hospitable gesture. Many people mistakenly believe that raw fish are highly nutritious and that the $\mathrm{L}_{3}$, if present within them, can be killed by the concurrent consumption of alcohol or hot spices. It is also known that smoking or pickling may not always be effective in killing $\mathrm{L}_{3}$ [1]. Adequate cooking is the most effective way of ensuring that the larvae are killed, although freezing infected food at $-20^{\circ} \mathrm{C}$ for $3-5$ days is also effective [1].

A high demand for exotic foods such as eel, loach, frog and snake has led to the rapid expansion of aquaculture around the world, and rivers, lakes and water reservoirs are now widely used to increase their cultivation [18]. Pigs are definitive hosts of Gnathostoma spp. Many small pig farms in developing countries are purposely built so that the swine feces end up in a pond/river/lake as feed for aquatic animals. However, pigs may be infected with Gnathostoma spp., in which case the eggs in their feces can act as the source of infection of intermediate hosts [84].

\section{Diagnosis}

The diagnosis of human gnathostomiasis is based on clinical symptoms and signs (intermittent subcutaneous or cutaneous migratory swelling), an elevated blood eosinophil level and a relevant exposure history (living in or traveling to endemic regions; ingesting raw or undercooked fish, frog or chicken) [85]. Subcutaneous gnathostomiasis commonly presents as a single nodule; in contrast, multiple nodules often exist in other parasitic infections such as sparganosis and cysticercosis [86]. A final diagnosis of gnathostomiasis can be established upon surgical removal of $\mathrm{L}_{3}$ or identification of the worms in a tissue specimen along with eosinophilia $[8,46,87]$. The accurate identification and differentiation of various Gnathostoma species have traditionally been based on morphological features [88]. However, the genus Gnathostoma includes 12 different species, five of which infect humans, that are virtually indistinguishable based on morphology, particularly at the larval and/or egg stages, which raises questions about Gnathostoma taxonomy [89].

Molecular techniques provide a definitive alternative approach to morphological identification and differentiation of Gnathostoma species. PCR-based approaches such as amplicon sequencing are a rapid and sensitive means of identification, and can be used for the phylogenetic analysis of different Gnathostoma species. The most commonly targeted genetic markers, namely nuclear small subunit ribosomal RNA (rRNA), internal transcribed spacer (ITS) regions of nuclear ribosomal DNA (rDNA) and the mitochondrial (mt) cytochrome c oxidase subunit 1 ( $\operatorname{cox} 1)$ gene, have been used to study genetic variation in Gnathostoma [90-93]. PCR-coupled 
sequencing and bioinformatics methods have also been used to identify and differentiate Gnathostoma in fixed and paraffin-embedded tissues, and can be used for the reappraisal of individual cases [94].

Gnathostomiasis can also be diagnosed using antigenspecific immunoglobulin G (IgG) antibodies, although the detection of Gnathostoma spp. larvae is the gold standard for its diagnosis. An enzyme-linked immunosorbent assay (ELISA) for $\mathrm{L}_{3}$ IgG antibodies has been developed. However, its sensitivity and specificity have been shown to be poor, i.e. $59-87 \%$ and $79-96 \%$, respectively [95]. Some studies reported a significant improvement in the diagnosis of human gnathostomiasis, although the $\operatorname{IgG}_{2}$ antibody showed cross-reactivity with several other nematode species [96]. Currently, an inability to accurately identify the infecting species of Gnathostoma is a major limitation in the diagnosis of human gnathostomiasis. Serological tests often show limited species identification due to antigenic cross-reactivity between species. A recent study indicated that recombinant MMPs of G. spinigerum can be used for the serodiagnosis of neurognathostomiasis [97].

Neuroimaging is non-specific and non-confirmatory, but can be used to complement serological tests to provide a presumptive diagnosis of human gnathostomiasis. Medical imaging techniques such as CT, MRI and ultrasonography can be used to assist the clinical diagnosis of patients with visceral disease [98-100]. MRI is superior to $\mathrm{CT}$ in the neuroimaging of cerebral larva migrans caused by Gnathostoma spp. A presumptive diagnosis of gnathostomiasis in cases where larvae have not been recovered can be reached by a combination of positive neuroimaging and immunoblot [60]. However, accurate diagnosis by imaging heavily depends upon infection intensity. Immunochromatographic test kits are promising diagnostic tools for rapid clinical diagnosis at the site of care and also for epidemiological surveys [101].

\section{Treatment and control}

There is no effective non-invasive treatment for human gnathostomiasis, and the surgical removal of larvae is considered the most effective treatment for this disease [1]. However, surgical removal is only feasible in cases of cutaneous or other types of superficial migration. For most cases of visceral gnathostomiasis, surgical removal is impracticable if not impossible. In these cases, various drugs (thiabendazole, praziquantel, metronidazole, diethylcarbamazine, and quinine) have been tested, but have shown no obvious efficacy [102].

Albendazole is the drug of first choice for human gnathostomiasis. A recommended dose of $400 \mathrm{mg}$ twice a day for 21 days resulted in a cure rate of $>90 \%$ [103]. Ivermectin has similar therapeutic efficacy to that reported for albendazole [104], and has been shown to be effective at either $0.2 \mathrm{mg} / \mathrm{kg}$ as a single dose or at $0.1 \mathrm{mg} /$ $\mathrm{kg}$ administered on 2 consecutive days. Corticosteroids may be administered alone (prednisolone, $60 \mathrm{mg} /$ day for 7 days), and cause the larvae to migrate and then die naturally [51]. Nevertheless, steroids should be used with

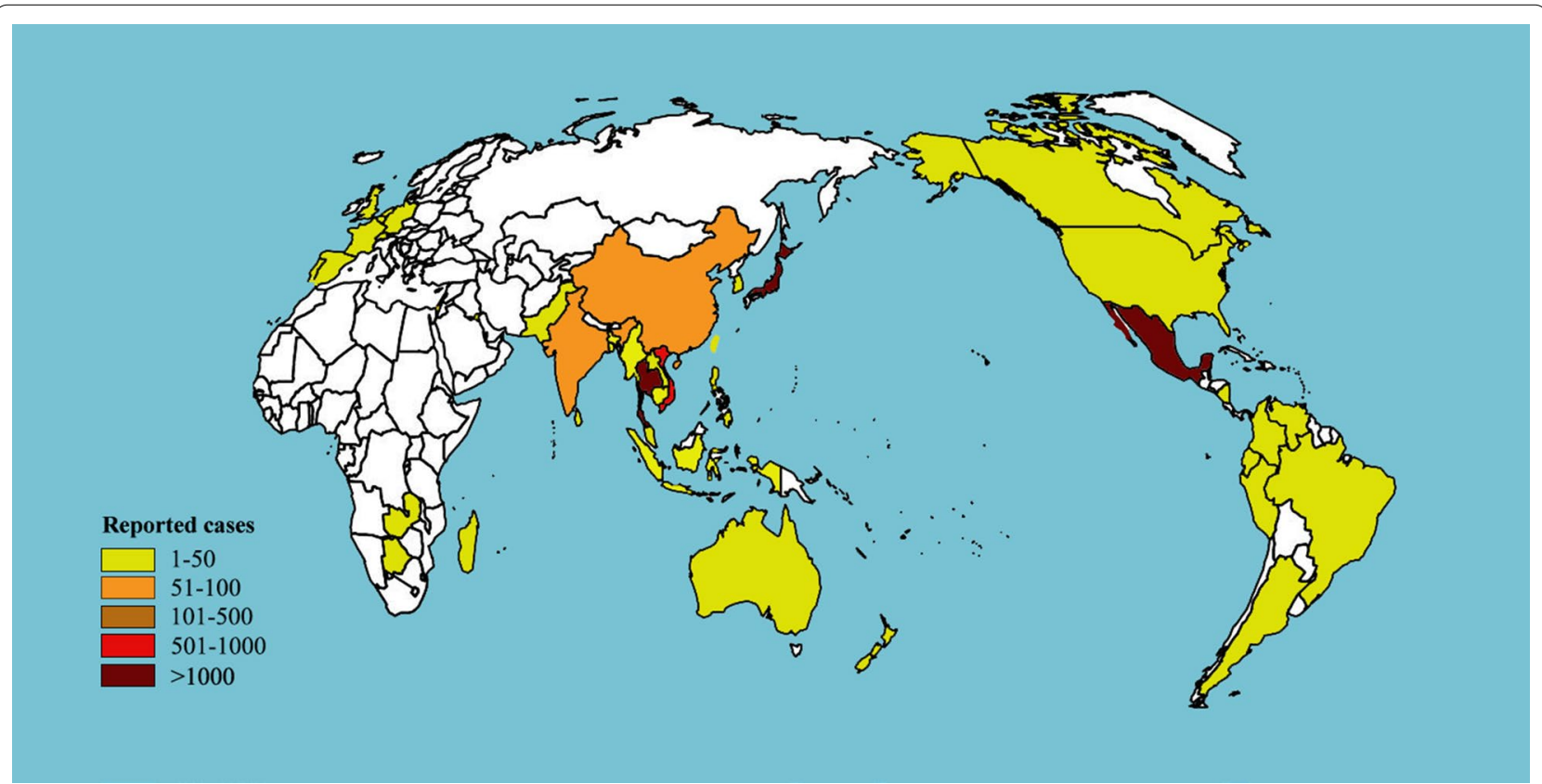

Fig. 2 Map of countries with reported cases of gnathostomiasis 
caution in cases of ocular or CNS gnathostomiasis due to their potential to cause further larval migration.

Initial chemotherapy is usually unsuccessful, as the majority of patients relapse and then require a second or even a third course of albendazole or ivermectin therapy. Relapses are often heralded by the appearance of peripheral eosinophilia [105]. However, in a few cases, albendazole or ivermectin has been used as an initial treatment with successful outcomes. A recent report by Gui et al. [106] showed that albendazole at $400 \mathrm{mg} /$ day for 10 days successfully cured two patients with pulmonary gnathostomiasis.

\section{New insights into human gnathostomiasis from the "omics" sciences}

The complete elucidation of four Gnathostoma $\mathrm{mt}$ genomes was an important step towards a better understanding of these parasites, and the disease that they cause, at the molecular level. Genomic data could prove useful for the reassessment of phylogenetic relationships, and for the development of next-generation diagnostics and therapeutic interventions. Complete $\mathrm{mt}$ genomes have been elucidated for G. spinigerum (14,079 bp) [107], Gnathostoma sp. (14,391 bp), G. nipponicum (14,093 bp) [108], and G. doloresi from China (13,809 bp) and Japan (13,812 bp) [109]. These $\mathrm{mt}$ genomes encompass 36 genes including two rRNA genes, 22 transfer RNA genes and 12 protein-coding genes with the atp 8 gene missing [107-109]. The inference of amino acid sequences from $\mathrm{mt}$ genome sequences is necessary for the systematic analysis of the relationships between Gnathostoma and other nematodes at the molecular level. Concatenated $\mathrm{mt}$ proteomic datasets have been shown to be very useful for re-examining the systematic relationships of different nematode groups [110-115]. Because of the strong phylogenetic signals and statistical support in phylogenetic trees generated from $\mathrm{mt}$ proteomic datasets of members of the suborder Spirurina [34, 116], it is now considered timely to examine the phylogenetic relationships of many spirurine nematodes. Molecular tools that use genetic markers such as rDNA ITS sequences and mt cox 1 have been examined for their application to the clinical diagnosis of Gnathostoma infection [91, 93]. Sequence heterogeneity in ITS rDNA can be high in individual nematode specimens [117], and the protein-coding genes of the $\mathrm{mt}$ genome are reasonably predicted to be better suited for this type of analysis [118]. This can be achieved by using PCR-coupled single-strand conformation polymorphism and DNA sequencing [119]. This technique has already been applied, on a small scale, to G. spinigerum [92]. A comparative study of DNA sequences indicated that the mt coxl gene can be used as a genetic marker for the identification and differentiation of Gnathostoma species
[93]. Mt cox1 sequences showed a relatively high degree of genetic variability (four distinct haplotypes) among G. spinigerum specimens from different host species (i.e. dogs, snakes and eels) and localities within Asia and Southeast Asia (i.e. China, Indonesia, Laos and Thailand) [120]. An assessment of the various haplotypes or genotypes of Gnathostoma and how they relate to different clinical signs of gnathostomiasis in humans would be useful.

Proteomic analyses of G. spinigerum are increasingly recognized for their value in the study of parasite biology and host-parasite interactions. Various biological and pathological functions of antigenic proteins of G. spinigerum have been identified, which include responses to stress, metabolic processes and energy generation, proteolysis, cell skeleton formation, protein folding, oxidation-reduction and carbohydrate ligand binding [121]. Immunoproteomic analysis has identified a number of antigenic proteins of $G$. spinigerum with potential as vaccine candidates for G. spinigerum infection.

Genome, developmental transcriptome and microRNA datasets constitute a collective resource for future investigations into the molecular biology, immunobiology, phylogenetics, epidemiology, population genetics and pathogenesis of Gnathostoma and/or gnathostomiasis. They should also be useful for the improvement of diagnostics and development of new drugs, including anthelmintics and vaccines [122]. Future studies should focus on: (i) sequencing and annotating the genome of G. spinigerum, and comparing it with those of other nematodes, with particular emphasis on excretory and secretory protein-encoding genes that are predicted to be involved in host invasion and parasite-host interactions; (ii) developmental transcriptome or microRNA datasets, which may prove useful for a better understanding of the biology and physiology of Gnathostoma nematodes.

\section{Conclusions and future directions}

While soil-transmitted helminths have received much attention because of their major socioeconomic impacts [123], other types of helminths such as Gnathostoma spp. have been largely neglected. Despite the fact that epidemiological studies of gnathostomiasis have been reported from many countries worldwide, gaps exist in our understanding of the epidemiology of Gnathostoma infection, and its zoonotic importance remains ill-defined. Combined with the lack of any estimate of the global burden of gnathostomiasis, all of these factors serve to limit a proper assessment of the public health impact and burden of gnathostomiasis.

Deciphering the genomes of Gnathostoma and their transcription will assist investigations into the immunobiology of this genus, as well as provide a genetic 
basis for the epidemiological study of these parasites. This will also facilitate studies on the biology, biochemistry, and physiology of these parasites, and the molecular mechanisms involved in their ability to modulate or evade the host immune system [124-126]. MicroRNAs have been assessed for their diagnostic value in several nematode infections [127-129], and the identification of specific biomarkers for the diagnosis of gnathostomiasis is a promising direction for future investigations.

The public health importance of helminthic infections, including gnathostomiasis, has been seriously neglected worldwide. The devastating consequences of this include the persistence and ever-increasing number of cases of gnathostomiasis, and the corresponding heavy disease burden. Human gnathostomiasis is now considered an important food-borne parasitic zoonosis $[15,130]$. Human beings are infected with Gnathostoma spp. mainly by consuming raw or undercooked food (fish, frogs, eel, poultry and snakes) that contains the parasite larvae. Dogs, cats, snakes, fish and birds all play important roles in the transmission of this disease. Recommended measures for the prevention and control of human gnathostomiasis primarily focus on educational campaigns in an effort to change eating habits. First, adequate cooking of potentially infected food is the safest way to ensure that larvae are killed, thereby preventing infection. Secondly, treating the definitive hosts, such as dogs and cats, with anthelmintics minimizes the source of infection. Thirdly, public awareness needs to be increased to promote a reduction in the hunting and sale of wildlife-especially wild birds, loaches, eels and snakes-for human consumption.

\section{Abbreviations \\ $\mathrm{AdL}_{3}$ : Advanced third-stage larvae; CNS: Central nervous system; cox1: Cytochrome c oxidase subunit 1; CT: Chromatographic test; ELISA: Enzyme- linked immunosorbent assay; $\mathrm{EL}_{3}$ : Early third-stage larvae; ES: Excretory-secre- tory; IgG: Immunoglobulin G; ITS: Internal transcribed spacer; $L_{1}$ : First-stage larvae; $L_{2}$ : Second-stage larvae; $L_{3}$ : Third-stage larvae; MMPs: Matrix metal- loproteinases; MRI: Magnetic resonance imaging; mt: Mitochondrial; PCR: Polymerase chain reaction; rDNA: Ribosomal DNA; rRNA: Ribosomal RNA.}

\section{Acknowledgments}

The authors are thankful to all the researchers whose studies have been reviewed in this manuscript.

\section{Authors' contributions \\ $\mathrm{X}-\mathrm{QZ}, \mathrm{CY}, \mathrm{HME}$, and $\mathrm{G}-\mathrm{HL}$ conceived the review. G-HL and M-MS wrote the first draft. X-QZ, CY, and HME reviewed and undertook the data abstraction from the selected articles, and revised the manuscript. HS, KA, and W-MS partici- pated in the preparation of the review. G-HL created the figures and assessed the data. Y-TF assisted in editing the review. All the authors read and approved the final version of the manuscript.}

\section{Funding}

This project was financially supported by the Training Program for Excellent Young Innovators of Changsha (grant no. KQ 1905013), the International
Science and Technology Cooperation Program of China (grant no. 2013DFA31840), and Shanxi Agricultural University.

Availability of data and materials

All datasets supporting the conclusions of this article are included within the article.

Ethics approval and consent to participate

Not applicable.

\section{Consent for publication}

Not applicable.

\section{Competing interests}

The authors declare that they have no competing interests.

\section{Author details}

${ }^{1}$ Hunan Provincial Key Laboratory of Protein Engineering in Animal Vaccines, College of Veterinary Medicine, Hunan Agricultural University, Changsha, 410128, Hunan, People's Republic of China. ${ }^{2}$ State Key Laboratory of Veterinary Etiological Biology, Key Laboratory of Veterinary Parasitology of Gansu Province, Lanzhou Veterinary Research Institute, Chinese Academy of Agricultural Sciences, Lanzhou 730046, Gansu, People's Republic of China. ${ }^{3}$ Faculty of Medicine and Health Sciences, School of Veterinary Medicine and Science, University of Nottingham, Sutton Bonington Campus, Loughborough LE12 5RD, UK. ${ }^{4}$ Department of Parasitology, National Institute of Infectious Diseases, Tokyo 162-8640, Japan. ${ }^{5}$ Department of Medical Zoology, Mie University School of Medicine, Mie 514-8507, Japan. ${ }^{6}$ Department of Parasitology and Tropical Medicine, Institute of Health Sciences, Gyeongsang National University College of Medicine, Jinju 52727, Korea. ${ }^{7}$ College of Veterinary Medicine, Shanxi Agricultural University, Taigu, Shanxi 030801, People's Republic of China. ${ }^{8}$ Department of Biomedical Sciences and One Health Center for Zoonoses and Tropical Veterinary Medicine, Ross University School of Veterinary Medicine, P.O. Box 334, Basseterre, St Kitts and Nevis.

Received: 15 September 2020 Accepted: 19 November 2020

Published online: 09 December 2020

\section{References}

1. Herman JS, Chiodini PL. Gnathostomiasis, another emerging imported disease. Clin Microbiol Rev. 2009;22:484-92.

2. Herman JS, Wall EC, van-Tulleken C, Godfrey-Faussett P, Bailey RL, Chiodini PL. Gnathostomiasis acquired by British tourists in Botswana. Emerg Infect Dis. 2009;15:594-7.

3. Diaz JH. Gnathostomiasis: an emerging infection of raw fish consumers in Gnathostoma nematode-endemic and nonendemic countries. J Travel Med. 2015a;22:318-24.

4. Prommas C, Daensgsvang S. Further report of a study of the life cycle of Gnathostoma spinigerum. J Parasitol. 1936;22:180-6.

5. Theunissen C, Bottieau E, Van Gompel A, Siozopoulou V, Bradbury RS. Presumptive Gnathostoma binucleatum infection in a Belgian traveler returning from South America. Travel Med Infect Dis. 2016;14:170-1.

6. Puente S, Gárate T, Grobusch MP, Janitschke K, Bru F, Rodríguez M, González-Lahoz JM. Two cases of imported gnathostomiasis in Spanish women. Eur J Clin Microbiol Infect Dis. 2002;21:617-20.

7. Parola P, Soula G, Gazin P, Foucault C, Delmont J, Brouqui P. Fever in travelers returning from tropical areas: prospective observational study of 613 cases hospitalised in Marseilles, France, 1999-2003. Travel Med Infect Dis. 2006;4:61-70.

8. Mulroy E, Simpson M, Frith R. Thoracic myelopathy due to gnathostomiasis acquired in New Zealand. Am J Trop Med Hyg. 2016;95:868-70.

9. Kim JH, Lim H, Hwang YS, Kim TY, Han EM, Shin EH, Chai JY. Gnathostoma spinigerum infection in the upper lip of a Korean woman: an autochthonous case in Korea. Korean J Parasitol. 2013;51:343-7.

10. Vargas TJ, Kahler S, Dib C, Cavaliere MB, Jeunon-Sousa MA. Autochthonous gnathostomiasis. Brazil Emerg Infect Dis. 2012;18:2087-9.

11. Jarell AD, Dans MJ, Elston DM, Mathison BA, Ruben BS. Gnathostomiasis in a patient who frequently consumes sushi. Am J Dermatopathol. 2011;33:e91-3. 
12. van Thiel PH, Jansen J. Is the case of presumed imported gnathostomiasis in the Netherlands a peculiar autochthonous case of anisakiasis? Acta Leiden. 1988;57:75-7.

13. McCarthy J, Moore TA. Emerging helminth zoonoses. Int J Parasitol. 2000;30:1351-60

14. Diaz JH. Increasing risk factors for imported and domestic gnathostomiasis in the United States. J LA State Med Soc. 2015b;167:215-9.

15. Dorny P, Praet N, Deckers N, Gabriel S. Emerging food-borne parasites. Vet Parasitol. 2009:163:196-206.

16. Owen R. Gnathostoma spinigerum n. sp. Proc Zool Soc. 1836;4:123-6.

17. Miyazaki I. On the genus Gnathostoma and human gnathostomiasis, with special reference to Japan. Exp Parasitol. 1960;9:338-70.

18. Cole RA, Choudhury A, Nico LG, Griffin KM. Gnathostoma spinigerum in live Asian swamp eels (Monopterus spp.) from food markets and wild populations, United States. Emerg Infect Dis. 2014;20:634-42.

19. Hem S, Tarantola A, Chheang R, Nop P, Kerléguer A. First reported case of intraocular Gnathostoma spinigerum in Cambodia. Bull Soc Pathol Exot. 2015;108:312-5.

20. Kim HS, Lee JJ, Joo M, Chang SH, Chi JG, Chai JY. Gnathostoma hispidum infection in a Korean man returning from China. Korean J Parasitol. 2010;48:259-61.

21. Akahane H, Shibue K, Shimizu A, Toshitani S. Human gnathostomiasis caused by Gnathostoma doloresi, with particular reference to the parasitological investigation of the causative agent. Ann Trop Med Parasitol. 1998;92:721-6.

22. Sato H, Kamiya H, Hanada K. Five confirmed human cases of gnathostomiasis nipponica recently found in northern Japan. J Parasitol. 1992;78:1006-10.

23. Ando K, Tanaka H, Taniguchi Y, Shimizu M, Kondo K. Two human cases of gnathostomiasis and discovery of a second intermediate host of Gnathostoma nipponicum in Japan. J Parasitol. 1988;74:623-7.

24. Chai JY, Sohn WM, Na BK, Park JB, Jeoung HG, Hoang EH, Htoon TT, Tin HH. Larval Gnathostoma spinigerum detected in Asian swamp eels, Monopterus albus, purchased from a local market in Yangon. Myanmar Korean J Parasitol. 2015;53:619-25.

25. Rusnak JM, Lucey DR. Clinical gnathostomiasis: case report and review of the English-language literature. Clin Infect Dis. 1993;16:33-50

26. Guitierrez Y. Diagnostic pathology of parasitic infections with clinical correlations. 2nd ed. Oxford: Oxford University Press; 2000.

27. Lv S, Zhang Y, Steinmann P, Zhou XN, Utzinger J. Helminth infection of the central nervous system occurring in Southeast Asia and the Far East. Adv Parasitol. 2010;72:351-408.

28. Nithiuthai S, Anantaphruti MT, Waikagul J, Gajadhar A. Waterborne zoonotic helminthiases. Vet Parasitol. 2004;126:167-93.

29. Daengsvang S, Sermswatsri B, Yongyi P. Spontaneous cure of the natural and induced Gnathostoma spinigerum infection in cats. Ann Trop Med Parasitol. 1969;64:489-91.

30. Lupi O, Downing C, Lee M, Pino L, Bravo F, Giglio P, Sethi A, Klaus S, Sangueza OP, Fuller C, Mendoza N, Ladizinski B, Woc-Colburn L, Tyring SK. Mucocutaneous manifestations of helminth infections: nematodes. J Am Acad Dermatol. 2015;73:929-44.

31. Hamilton WL, Agranoff D. Imported gnathostomiasis manifesting as cutaneous larva migrans and Löffler's syndrome. BMJ Case Rep. 2018;2:2018.

32. Gao ST. Epidemiology, clinical picture, diagnosis and treatment of gnathostomiasis. China Trop Med. 2014;14:1136-9.

33. Germann R, Schachtele M, Nessler G, Seitz U, Kniehl E. Cerebral gnathostomiasis as a cause of an extended intracranial bleeding. Klin Padiatr. 2003:215:223-5.

34. Moore DA, McCroddan J, Dekumyoy P, Dini CPL. Gnathostomiasis: an emerging imported disease. Emerg Infect Dis. 2003;9:647-50.

35. Anthony RM, Rutitzky LI, Urban JF Jr, Stadecker MJ, Gause WC. Protective immune mechanisms in helminth infection. Nat Rev Immunol. 2007;7:975-87.

36. Mulcahy G, O'Neill S, Fanning J, McCarthy E, Sekiya M. Tissue migration by parasitic helminths-an immunoevasive strategy? Trends Parasitol. 2005;21:273-7.

37. Benjathummarak S, Kumsiri R, Nuamtanong S, Kalambaheti T, Waikagul J, Viseshakul N, Maneerat Y. Third-stage Gnathostoma spinigerum larva excretory secretory antigens modulate function of Fc gamma receptor
I-mediated monocytes in peripheral blood mononuclear cell culture. Trop Med Health. 2016;44:5.

38. Viseshakul N, Dechkhajorn W, Benjathummarak S, Nuamtanong S, Maneerat Y. Excretory-secretory product of third-stage Gnathostoma spinigerum larvae induces apoptosis in human peripheral blood mononuclear cells. Parasitol Res. 2017;116:2783-94.

39. Chaves CM, Chaves C, Zoroquiain P, Belfort R Jr, Burnier MN Jr. Ocular gnathostomiasis in Brazil: a case report. Ocul Oncol Pathol. 2016:2:194-6.

40. Magana M, Messina M, Bustamante F, Cazarín J. Gnathostomiasis: clinicopathologic study. Am J Dermatopathol. 2004;26:91-5.

41. Cui J, Wang Y, Wang ZQ. Cutaneous gnathostomiasis with recurrent migratory nodule and persistent eosinophilia: a case report from China. Korean J Parasitol. 2013:51:467-70.

42. Laga AC, Lezcano C, Ramos C, Costa H, Chian C, Salinas C, Salomon M, del Solar M, Bravo F. Cutaneous gnathostomiasis: report of 6 cases with emphasis on histopathological demonstration of the larva. J Am Acad Dermatol. 2013;68:301-5.

43. Suntharasamai P, Riganti M, Chittamas S, Desakorn V. Albendazole stimulates outward migration of Gnathostoma spinigerum to the dermis in man. Southeast Asian J Trop Med Public Health. 1992;23:716-22.

44. Ménard A, Santos GD, Dekumyoy P, Ranque S, Delmont J, Danis M, Bricaire F, Caumes E. Imported cutaneous gnathostomiasis: report of five cases. Trans R Soc Trop Med Hyg. 2003;97:200-2.

45. Shreekant T, Nirupama C, Bibhudutta R. Intraocular Gnathostoma spinigerum: a case report. Cases J. 2009;2:9370.

46. Baquera-Heredia J, Cruz-Reyes A, Flores-Gaxiola A, López-Pulido G, Díaz Simental E, Valderrama-Valenzuela L. A case of ocular gnathostomiasis in northwestern Mexico. Am J Trop Med Hyg. 2002;66:572-4.

47. Diaz Camacho SP, Zazueta Ramos M, Ponce Torrecillas E, Osuna Ramirez I, Castro Velazquez R, Flores Gaxiola A, Baquera Heredia J, Willms K, Akahane H, Ogata K, Nawa Y. Clinical manifestations and immunodiagnosis of gnathostomiasis in Culiacan, México. Am J Trop Med Hyg. 1998:59:908-15.

48. Preeti R, Manushree G, Jain NC, Jain R. Intraocular gnathostomiasis: a rare case report from central India. Indian J Ophthalmol. 2016;64:235.

49. Intapan PM, Morakote N, Chansung K, Maleewong W. Hypereosinophilia and abdominopulmonary gnathostomiasis. Southeast Asian $J$ Trop Med Public Health. 2008;39:804-7.

50. Nitidandhaprabhas $P$, Sirimachan S, Charnvises K. A case of penile gnathostomiasis in Thailand. Am J Trop Med Hyg. 1978;27:1282-3.

51. Horohoe JJ, Ritterson AL, Chessin LN. Urinary gnathostomiasis. JAMA. 1984;251:255-6.

52. Nitidandhaprabhas $P$, Sirikarna A, Harnsomburana K, Thepsitthar P. Human urinary gnathostomiasis: a case report from Thailand. Am J Trop Med Hyg. 1975;24:49-51.

53. Kulkarni S, Sayed R, Garg M, Patil V. Neurognathostomiasis in a young child in India: a case report. Parasitol Int. 2015;64:342-4.

54. Katchanov J, Sawanyawisuth K, Chotmongkol V, Nawa Y. Neurognathostomiasis, a neglected parasitosis of the central nervous system. Emerg Infect Dis. 2011;17:1174-80.

55. Nawa Y. Historical review and current status of gnathostomiasis in Asia. Southeast Asian J Trop Med Public Health. 1991;22:217-9.

56. Boongird P, Phuapradit P, Siridej N, Chirachariyavej T, Chuahirun S, Vejjajiva A. Neurological manifestations of gnathostomiasis. J Neurol Sci. 1977;31:279-91.

57. Daengsvang S. Human gnathostomiasis in Siam with reference to the method of prevention. J Parasitol. 1949;35:116-21.

58. Chitanondh H, Rosen L. Fatal eosinophilic encephalomyelitis caused by the nematode Gnathostoma spinigerum. Am J Trop Med Hyg. 1967;16:638-45.

59. Maruyama H, Nawa Y. Immunology of the infection. In: Murrell KD, Fried B, editors. Worldclass parasites. Food-borne parasitic zoonoses. BerlinNew York: Springer; 2007. p. 337-81.

60. Caballero-García Mde L, Almeyda-Artigas RJ, Mosqueda-Cabrera MA, Jiménez-Cardoso E. Gnathostoma binucleatum: excretion-secretion antigen analysis obtained from advanced third-stage larvae in in vitro culture. Exp Parasitol. 2005;110:140-5.

61. Katchanov J, Nawa Y. Helminthic invasion of the central nervous system: many roads lead to Rome. Parasitol Int. 2010:59:491-6. 
62. Punyagupta S, Limtrakul C, Vichipanthu P, Karnchanachetanee C, Nye SW. Radiculomyeloencephalitis associated with eosinophilic pleocytosis-report of nine cases. Am J Trop Med Hyg. 1968;17:551-60.

63. Sithinamsuwan $P$, Chairangsaris P. Images in clinical medicine. Gnathostomiasis-neuroimaging of larval migration. N Engl J Med. 2005;353:188.

64. Schmutzhard E, Boongird P, Vejjajiva A. Eosinophilic meningitis and radiculomyelitis in Thailand, caused by CNS invasion of Gnathostoma spinigerum and Angiostrongylus cantonensis. J Neurol Neurosurg Psychiatry. 1988;51:80-7.

65. Rojekittikhun W, Pubampen S. Morphological variation and abnormality of cephalic hooklets of Gnathostoma spinigerum hepatic stage larvae from laboratory infected mice. Southeast Asian J Trop Med Public Health. 1998;29:118-22.

66. Sawanyawisuth K, Tiamkao S, Kanpittaya J, Dekumyoy P, Jitpimolmard S. MR imaging findings in cerebrospinal gnathostomiasis. AJNR Am J Neuroradiol. 2004:25:446-9.

67. Nawa Y, Yoshikawa M, Sawanyawisuth K, Chotmongkol V, Figueiras SF, Benavides M, Diaz Camacho SP. Ocular gnathostomiasis-update of earlier survey. Am J Trop Med Hyg. 2017;97:1232-4.

68. Nawa Y, Katchanov J, Yoshikawa M, Rojekittikhun W, Dekumyoy P, Kusolusuk T, Wattanakulpanich D. Ocular gnathostomiasis: a comprehensive review. J Trop Med Parasitol. 2008;32:77-86.

69. Nawa Y, Imai J, Ogata K, Otsuka K. The first record of a human case of Gnathostoma doloresi infection. J Parasitol. 1989;75:166-9.

70. Sakamoto M, Sato F, Mizuno Y, Komatsuzaki M, Yoshikawa K, Yoshida M, Shiba K, Onodera S, Hosoya T, Kumagai M. Gnathostomiasis caused by Gnathostoma spinigerum etiologically diagnosed upon extraction of the worm from the skin. Kansenshogaku Zasshi. 2004;78:442-5.

71. Nawa Y, Maruyama H, Ogata K. Current status of gnathostomiasis dorolesi in Miyazaki Prefecture, Japan. Southeast Asian J Trop Med Public Health. 1997;28:11-3.

72. Seguchi K, Matsuno M, Kataoka H, Kobayashi T, Maruyama H, Itoh H, Koono M, Nawa Y. A case report of colonic ileus due to eosinophilic nodular lesions caused by Gnathostoma doloresi infection. Am J Trop Med Hyg. 1995;53:263-6.

73. Taniguchi Y, Ando K, Isoda K, Shimizu M, Sonobe K. Human gnathostomiasis: successful removal of Gnathostoma hispidum. Int J Dermatol. 1992:31:175-7.

74. Kawamura J, Kohri Y, Oka N. Eosinophilic meningoradiculomyelitis caused by Gnathostoma spinigerum. A case report. Arch Neurol. 1983:40:583-5.

75. Bussaratid V, Dekumyoy P, Desakorn V, Jaroensuk N, Liebtawee B, Pakdee W, Wattanagoon Y. Predictive factors for Gnathostoma seropositivity in patients visiting the gnathostomiasis clinic at the hospital for tropical diseases, Thailand during 2000-2005. Southeast Asian J Trop Med Public Health. 2010;41:1316-21.

76. Li DM, Chen XR, Zhou JS, Xu ZB, Nawa Y, Dekumyoy P. Short report: case of gnathostomiasis in Beijing, China. Am J Trop Med Hyg. 2009;80:185-7.

77. Chen QQ, Lin XM. Chinese gnathostoma and gnathostomiasis. Wuyi Sci J. 1992;11:221-44

78. Ma XT, Li SG, Bai YP, Zheng ZC. A case of skin gnathostomiasis. J Practical Dermatol. 2015;137-8.

79. Ma A, Gan XX. A case of gnathostomiasis in Hangzhou City. Chin J Zoonoses. 2009;25:709.

80. Zhang SK, Zeng QR, Zeng XF. A case of gnathostomiasis. J Hunan Medical Univ. 1998:422

81. Wu HF, Zhang HM. Research progress in gnathostomiasis. Appl Prev Med. 2009;15:380-3.

82. Phan VT, Ersbø\|l AK, Do DT, Dalsgaard A. Raw-fish-eating behavior and fishborne zoonotic trematode infection in people of northern Vietnam. Foodborne Pathog Dis. 2011;8:255-60.

83. Vandamme SG, Griffiths AM, Taylor SA, Di Muri C, Hankard EA, Towne JA, Watson M, Mariani S. Sushi barcoding in the UK: another kettle of fish. PeerJ. 2016;4:e1891.

84. Borthakur SK, Mukharjee SN. Gastrointestinal helminthes in stray cats (Felis catus) from Aizawl, Mizoram, India. Southeast Asian J Trop Med Public Health. 2011;42:255-8.

85. Buppajarntham A, Apisarnthanarak A, Khawcharoenporn T, Rutjanawech S, Mundy LM. Asymptomatic eosinophilia due to gnathostomiasis. Int J Infect Dis. 2014:23:14-5.
86. Liu Q, Li MW, Wang ZD, Zhao GH, Zhu XQ. Human sparganosis, a neglected food borne zoonosis. Lancet Infect Dis. 2015;15:1226-35.

87. Jongthawin J, Intapan PM, Sanpool O, Sadaow L, Janwan P, Thanchomnang T, Sangchan A, Visaetsilpanonta S, Keawkong W, Maleewong W. Three human gnathostomiasis cases in Thailand with molecular identification of causative parasite species. Am J Trop Med Hyg. 2015;93:615-8.

88. Sohn WM, Lee SH. The first discovery of larval Gnathostoma hispidum (Nematoda: Gnathostomidae) from a snake host Agkistrodon brevicaudus. Korean J Parasitol. 1998;36:81-9.

89. Bertoni-Ruiz F, García-Prieto L, Osorio-Sarabia D, León-Règagnon V. A new species of Gnathostoma (Nematoda: Gnathostomatidae) in Procyon lotor hernandezii from Mexico. J Parasitol. 2005;91:1143-9.

90. Cernotíková E, Horák A, Moravec F. Phylogenetic relationships of some spirurine nematodes (Nematoda: Chromadorea: Rhabditida: Spirurina) parasitic in fishes inferred from SSU rRNA gene sequences. Folia Parasitol. 2011;58:135-48.

91. Almeyda-Artigas RJ, Barques MD, Mas-Coma S. ITS-2 rDNA sequencing of Gnathostoma species (Nematoda) and elucidation of the species causing human gnathostomiasis in the Americas. J Parasitol. 2000;86:537-44.

92. Ngarmamonpirat C, Waikagul J, Petmitr S, Dekumyoy P, Rojekittikhun W, Anantapruti MT. Analysis of sequence variation in Gnathostoma spinigerum mitochondrial DNA by single-strand conformation polymorphism analysis and DNA sequence. Parasitol Int. 2005;54:65-8.

93. Ando K, Tsunemori M, Akahane H, Tesana S, Hasegawa H, Chinzei Y. Comparative study on DNA sequences of ribosomal DNA and cytochrome $c$ oxidase subunit 1 of mitochondrial DNA among five species of gnathostomes. J Helminthol. 2006;80:7-13.

94. Wongkamchai S, Mayoon B, Kanakul N, Foongladda S, Wanachiwanawin D, Nochote H, Loymek S. Rapid differentiation of filariae in unstained and stained paraffin-embedded sections by a high-resolution melting analysis PCR assay. Vector Borne Zoonotic Dis. 2015;15:473-80.

95. Maleewong W, Morakote N, Thamasonthi W, Charuchinda K, Tesana S, Khamboonruang C. Serodiagnosis of human gnathostomiasis. Southeast Asian J Trop Med Public Health. 1988;19:201-5.

96. Tapchaisri P, Nopparatana C, Chaicumpa W, Setasuban P. Intradermal reaction with Gnathostoma spinigerum antigen. Jpn J Parasitol. 1991;21:315-9.

97. Janwan P, Intapan PM, Yamasaki H, Laummaunwai P, Sawanyawisuth K, Wongkham C, Tayapiwatana C, Kitkhuandee A, Lulitanond V, Nawa Y, Maleewong W. A recombinant matrix metalloproteinase protein from Gnathostoma spinigerum for serodiagnosis of neurognathostomiasis. Korean J Parasitol. 2013;51:751-4.

98. Kanpittaya J, Sawanyawisuth K, Intapan PM, Khotsri P, Chotmongkol V, Maleewong W. A comparative study of neuroimaging features between human neuro-gnathostomiasis and angiostrongyliasis. Neurol Sci. 2012;33:893-8

99. Chotmongkol V, Kitkhuandee A, Sawanyawisuth K. Spinal epidural hematoma and gnathostomiasis. Am J Trop Med Hyg. 2015;92:677.

100. Bhende M, Biswas J, Gopal L. Ultrasound biomicroscopy in the diagnosis and management of intraocular gnathostomiasis. Am J Ophthalmol. 2005:140:140-2.

101. Janwan P, Intapan PM, Yamasaki H, Rodpai R, Laummaunwai P, Thanchomnang T, Sanpool O, Kobayashi K, Takayama K, Kobayashi Y, Maleewong W. Development and usefulness of an immunochromatographic device to detect antibodies for rapid diagnosis of human gnathostomiasis. Parasites Vectors. 2016;9:14

102. Kraivichian P, Kulkumthorn M, Yingyourd P, Akarabovorn P, Paireepai CC Albendazole for the treatment of human gnathostomiasis. Trans R Soc Trop Med Hyg. 1992;86:418-21.

103. Vanegas ES, Cendejas RF, Mondragón A. A 41-year-old woman with migratory panniculitis. Am J Trop Med Hyg. 2014;90:786-7.

104. Nontasut P, Bussaratid V, Chullawichit S, Charoensook N, Visetsuk K. Comparison of ivermectin and albendazole treatment for gnathostomiasis. Southeast Asian J Trop Med Public Health. 2000;31:374-7.

105. Strady C, Dekumyoy P, Clement-Rigolet M, Danis M, Bricaire F, Caumes E. Long-term follow-up of imported gnathostomiasis shows frequent treatment failure. Am J Trop Med Hyg. 2009;80:33-5. 
106. Gui XH, Cao M, Zhang YW, Cai HR, Xiao YL. Pulmonary gnathostomiasis: two cases report and review of literature. Chin J Respir Crit Care Med. 2013:12:177-81.

107. Liu GH, Shao R, Cai XQ, Li WW, Zhu XQ. Gnathostoma spinigerum mitochondrial genome sequence: a novel gene arrangement and its phylogenetic position within the class Chromadorea. Sci Rep. 2015;5:12691.

108. Sun MM, Ma J, Sugiyama H, Ando K, Li WW, Xu QM, Liu GH, Zhu XQ. The complete mitochondrial genomes of Gnathostoma doloresi from China and Japan. Parasitol Res. 2016:115:4013-20.

109. Sun MM, Liu GH, Ando K, Woo HC, Ma J, Sohn WM, Sugiyama H, Zhu $\mathrm{XQ}$. Complete mitochondrial genomes of Gnathostoma nipponicum and Gnathostoma sp., and their comparison with other Gnathostoma species. Infect Genet Evol. 2017;48:109-15.

110. Xu WW, Qiu JH, Liu GH, Zhang Y, Liu ZX, Duan H, Yue DM, Chang QC, Wang CR, Zhao XC. The complete mitochondrial genome of Strongylus equinus (Chromadorea: Strongylidae): comparison with other closely related species and phylogenetic analyses. Exp Parasitol. 2015;159:94-9.

111. Liu GH, Li S, Zou FC, Wang CR, Zhu XQ. The complete mitochondrial genome of rabbit pinworm Passalurus ambiguus: genome characterization and phylogenetic analysis. Parasitol Res. 2016;115:423-9.

112. Liu SS, Liu GH, Zhu XQ, Weng YB. The complete mitochondrial genome of Pseudoterranova azarasi and comparative analysis with other anisakid nematodes. Infect Genet Evol. 2015;33:293-8.

113. Liu GH, Jia YQ, Wang YN, Zhao GH, Zhu XQ. The complete mitochondrial genome of the gullet worm Gongylonema pulchrum: gene content, arrangement, composition and phylogenetic implications. Parasites Vectors. 2015;8:100

114. Jabbar A, Littlewood DT, Mohandas N, Briscoe AG, Foster PG, Müller F, von Samson-Himmelstjerna G, Jex AR, Gasser RB. The mitochondrial genome of Parascaris univalens-implications for a "forgotten" parasite. Parasites Vectors. 2014;7:428.

115. Liu GH, Gasser RB, Su A, Nejsum P, Peng L, Lin RQ, Li MW, Xu MJ, Zhu $X Q$. Clear genetic distinctiveness between human- and pig-derived Trichuris based on analyses of mitochondrial datasets. PLOS Negl Trop Dis. 2012;6:e1539.

116. Kim J, Kern E, Kim T, Sim M, Kim J, Kim Y, Park C, Nadler SA, Park JK. Phylogenetic analysis of two Plectus mitochondrial genomes (Nematoda: Plectida) supports a sister group relationship between Plectida and Rhabditida within Chromadorea. Mol Phylogenet Evol. 2017:107:90-102

117. Gasser RB, LeGoff L, Petit G, Bain O. Rapid delineation of closely-related filarial parasites using genetic markers in spacer rDNA. Acta Trop. 1996;62:143-50

118. Blouin MS. Molecular prospecting for cryptic species of nematodes: mitochondrial DNA versus internal transcribed spacer. Int J Parasitol. 2002;32:527-31.

119. Gasser RB, Korhonen PK, Zhu XQ, Young ND. Harnessing the Toxocara genome to underpin toxocariasis research and new interventions. Adv Parasitol. 2016:91:87-110.
120. Eamsobhana P, Wanachiwanawin D, Roongruangchai K, Song SL, Yong HS. Genetic diversity of infective larvae of Gnathostoma spinigerum (Nematoda: Gnathostomatidae) in freshwater swamp eels from Thailand. J Helminthol. 2017;91:767-71.

121. Janwan P, Intapan PM, Laummaunwai P, Rodpai R, Wongkham C, Insawang T, Thanchomnang T, Sanpool O, Maleewong W. Proteomic analysis identification of antigenic proteins in Gnathostoma spinigerum larvae. Exp Parasitol. 2015;159:535-8.

122. Ma G, Holland CV, Wang T, Hofmann A, Fan CK, Maizels RM, Hotez PJ, Gasser RB. Human toxocariasis. Lancet Infect Dis. 2018;18:e14-24.

123. Bethony J, Brooker S, Albonico M, Geiger SM, Loukas A, Diemert D, Hotez PJ. Soil-transmitted helminth infections: ascariasis, trichuriasis, and hookworm. Lancet. 2006:367:1521-32.

124. Gasser RB, Tan P, Teh BT, Wongkham S, Young ND. Genomics of worms, with an emphasis on Opisthorchis viverrini-opportunities for fundamental discovery and biomedical outcomes. Parasitol Int. 2017;66:341-5.

125. Zhu XQ, Korhonen PK, Cai H, Young ND, Nejsum P, von Samson-Himmelstjerna G, Boag PR, Tan P, Li Q, Min J, Yang Y, Wang X, Fang X, Hall RS, Hofmann A, Sternberg PW, Jex AR, Gasser RB. Genetic blueprint of the zoonotic pathogen Toxocara canis. Nat Commun. 2015;6:6145.

126. Jex AR, Nejsum P, Schwarz EM, Hu L, Young ND, Hall RS, Korhonen PK, Liao S, Thamsborg S, Xia J, Xu P, Wang S, Scheerlinck JP, Hofmann A, Sternberg PW, Wang J, Gasser RB. Genome and transcriptome of the porcine whipworm Trichuris suis. Nat Genet. 2014;46:701-6.

127. Lagatie O, Batsa Debrah L, Debrah A, Stuyver LJ. Plasma-derived parasitic microRNAs have insufficient concentrations to be used as diagnostic biomarkers for detection of Onchocerca volvulus infection or treatment monitoring using LNA-based RT-qPCR. Parasitol Res. 2017;116:1013-22.

128. Kulkarni AP, Mittal SP. Sequence data mining in search of hookworm (Necator americanus) microRNAs. Gene. 2016;590:317-23.

129. Kogure A, Uno M, Ikeda T, Nishida E. The microRNA machinery regulates fasting-induced changes in gene expression and longevity in Caenorhabditis elegans. J Biol Chem. 2017;292:11300-9.

130. Magnino S, Colin P, Dei-Cas E, Madsen M, McLauchlin J, Nöckler K, Maradona MP, Tsigarida E, Vanopdenbosch E, Van Peteghem C. Biological risks associated with consumption of reptile products. Int J Food Microbiol. 2009;134:163-75

\section{Publisher's Note}

Springer Nature remains neutral with regard to jurisdictional claims in published maps and institutional affiliations.

\footnotetext{
Ready to submit your research? Choose BMC and benefit from:

- fast, convenient online submission

- thorough peer review by experienced researchers in your field

- rapid publication on acceptance

- support for research data, including large and complex data types

- gold Open Access which fosters wider collaboration and increased citations

- maximum visibility for your research: over $100 \mathrm{M}$ website views per year
}

At BMC, research is always in progress.

Learn more biomedcentral.com/submissions 